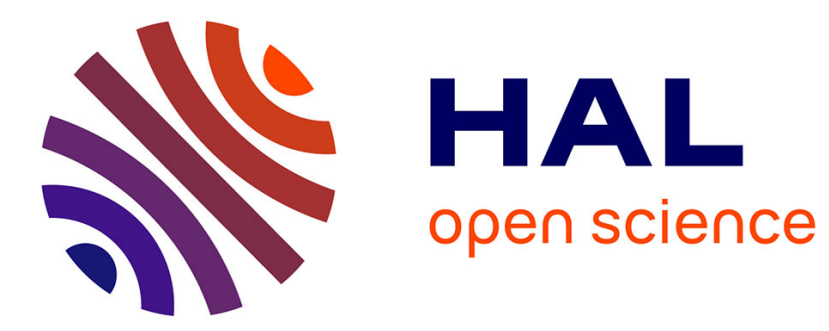

\title{
Spark Plasma Sintering of Ceramic Matrix Composites with self healing matrix
}

Jérôme Magnant, Laurence Maillé, René Pailler, Alain Guette

\section{To cite this version:}

Jérôme Magnant, Laurence Maillé, René Pailler, Alain Guette. Spark Plasma Sintering of Ceramic Matrix Composites with self healing matrix. Ceramic Engineering and Science Proceedings, 2014, 35 (2), pp.177-186. hal-01845209

\section{HAL Id: hal-01845209 https://hal.science/hal-01845209}

Submitted on $20 \mathrm{Jul} 2018$

HAL is a multi-disciplinary open access archive for the deposit and dissemination of scientific research documents, whether they are published or not. The documents may come from teaching and research institutions in France or abroad, or from public or private research centers.
L'archive ouverte pluridisciplinaire HAL, est destinée au dépôt et à la diffusion de documents scientifiques de niveau recherche, publiés ou non, émanant des établissements d'enseignement et de recherche français ou étrangers, des laboratoires publics ou privés. 


\title{
Spark Plasma Sintering of Ceramic Matrix Composites with self healing matrix
}

Jerome Magnant; Laurence Maille*, René Pailler; Alain Guette

University of Bordeaux, LCTS-UMR 5801, Pessac, France.

\begin{abstract}
The processing of dense Ceramic Matrix Composites (CMC) by a short time and so by low cost process was studied. This process is based on $(i)$ the chemical vapor deposition of carbon interphase on the fiber surface, (ii) the introduction of mineral powders inside the multidirectional continuous fiber preform and (iii) the densification of the matrix by Spark Plasma Sintering (SPS). To prevent carbon fibers and interphase from oxidation in service, a self-healing matrix made of silicon nitride and titanium diboride was processed. A thermal treatment of 3 minutes at $1500^{\circ} \mathrm{C}$ allows to fully consolidate by SPS the composite without fiber degradation. The ceramic matrix composites obtained have an ultimate bending stress at room temperature around $300 \mathrm{MPa}$ and show a self-healing behaviour in oxidizing conditions.
\end{abstract}

Keywords: Ceramic-matrix composites (CMCs); Spark Plasma Sintering.

\section{INTRODUCTION}

The strengthening and toughening of silicon nitride by reinforcement with continuous fibers has received considerable attention in recent years. $\mathrm{Si}_{3} \mathrm{~N}_{4}$ reinforced with carbon fibers can be fabricated by high temperature sintering under pressure: HP-HIP [1] at $1800^{\circ} \mathrm{C}$ or by Spark Plasma Sintering (SPS) [2] at $1650^{\circ} \mathrm{C}$. The coefficient of thermal expansion (CTE) of carbon fibers is anisotropic (it is very low and

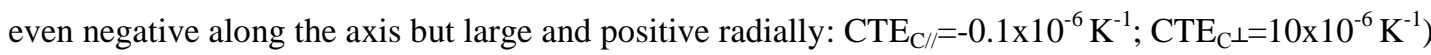
and different from that of $\mathrm{Si}_{3} \mathrm{~N}_{4}\left(\mathrm{CTE}_{\mathrm{Si} 3 \mathrm{~N} 4}=2.8-3.5 \times 10^{-6} \mathrm{~K}^{-1}\right)$. As a result, $\mathrm{CMC}$ as $\mathrm{C} / \mathrm{Si}_{3} \mathrm{~N}_{4}$ composites already exhibit a microcracked matrix in the as-prepared state, these microcracks facilitating the in-depth oxygen diffusion toward the oxidation prone carbon fibers when exposed to oxidizing atmosphere [3]. Indeed carbon fibers undergo active oxidation at very low temperature $\left(\approx 450^{\circ} \mathrm{C}\right)$. Hence, to obtain C-fiber reinforced CMC, which have a long lifetime (thousands of hours and even more) under load at high temperature and in oxidizing atmospheres, extensive researches have been carried out during the last decades. The solutions proposed are (i) the utilization of SiC fibers instead of C fibers [4] (but SiC fibers 
with good mechanical properties at high temperature are far more expensive than $\mathrm{C}$ fiber), (ii) the development of innovative self-healing interphases and matrices [5] and (iii) the development of specific coatings (environmental barriers coating) $[6,7]$.

The concept of self-healing interphases and matrices is based on the presence of elements as boron compounds $\left(\mathrm{B}_{4} \mathrm{C}, \mathrm{BN}, \mathrm{TiB}_{2}, \ldots\right)$ or silicon compounds $\left(\mathrm{SiC}, \mathrm{Si}_{3} \mathrm{~N}_{4}, \ldots\right)$ which form fluid oxide phases at high temperature when exposed to oxidizing atmosphere. This liquid oxide could fill the cracks rendering the interphase or the matrix self-healing. CMC with self-healing matrix were successfully fabricated by Chemical Vapor Infiltration (CVI) [8], but display long time and high cost production due to the intrinsic characteristics of the gaseous process and are not fully dense. In this work, carbon fiber composite with a dense self-healing matrix fabricated by a new short time process was studied. The hybrid process used for the fabrication of the composite is based (i) on CVI fiber coating, (ii) on slurry infiltration of ceramic powders into the multidirectional-continuous fiber preforms and (iii) on densification by Spark Plasma Sintering of the composite. This process was developed in our laboratory and has been reported somewhere else [2]. The matrix is a ceramic constituted of $\mathrm{Si}_{3} \mathrm{~N}_{4}$ and $\mathrm{TiB}_{2}$ phases. $\mathrm{Si}_{3} \mathrm{~N}_{4}$ is the main constituent and was choosen for its excellent thermomechanical properties such as high strength, hardness, toughness, good thermal shock and oxidation resistance as well as for its lower sintering temperature in comparison of $\mathrm{SiC}$ and consequently lower manufacturing cost [9].

Titanium diboride exhibits a high melting point $\left(\sim 2900^{\circ} \mathrm{C}\right)$, a high hardness and has the faculty to form fluid healing $\mathrm{B}_{2} \mathrm{O}_{3}$ phase as soon as $470^{\circ} \mathrm{C}$ under oxidizing conditions [9-12]. Furthemore, the high elastic modulus and coefficient of thermal expansion of $\mathrm{TiB}_{2}$ with respect to $\mathrm{Si}_{3} \mathrm{~N}_{4}$ contribute to potential toughening mechanisms [13]. $\mathrm{Si}_{3} \mathrm{~N}_{4}+\mathrm{TiB}_{2}$ particulate composites with good mechanical properties were successfully processed by HP and HIP $[13,14]$. The aims of this paper are first, to determine the sintering conditions of the unreinforced $\mathrm{Si}_{3} \mathrm{~N}_{4} / \mathrm{TiB}_{2}$ ceramic matrix by Spark Plasma Sintering, second, to process carbon-fibers composites with $\mathrm{Si}_{3} \mathrm{~N}_{4} / \mathrm{TiB}_{2}$ matrix, densified by SPS process and, third, to evaluate their mechanical and self-healing properties. 


\section{EXPERIMENTAL METHOD}

\subsection{Elaboration of monolithic matrix}

In order to perform the ceramic matrix, sub-micronic powders of $\mathrm{Si}_{3} \mathrm{~N}_{4}, \mathrm{TiB}_{2}, \mathrm{Al}_{2} \mathrm{O}_{3}$, and $\mathrm{Y}_{2} \mathrm{O}_{3}$ were used (Table I). The proportion of the different constituent was $66.5 \mathrm{wt} \% \mathrm{Si}_{3} \mathrm{~N}_{4}+20 \mathrm{wt} \% \mathrm{TiB}_{2}+4.5 \mathrm{wt} \%$ $\mathrm{Al}_{2} \mathrm{O}_{3}+9 \mathrm{wt} \% \mathrm{Y}_{2} \mathrm{O}_{3}$. Yttria and alumina are sintering-aids and react in temperature with the silica layer covering the surface of silicon nitride powders to form a liquid phase that firstly promotes the densification of $\mathrm{Si}_{3} \mathrm{~N}_{4}$. Titanium diboride is the self-healing phase and was also reported to promote the densification of $\mathrm{Si}_{3} \mathrm{~N}_{4}$ at low temperatures [12].

Powders were mixed by wet ball-milling in polyethylene pots with ethanol and $\mathrm{Al}_{2} \mathrm{O}_{3}$ balls during 24 hours. Then, mixed powders were dried and milled by dry ball-milling in polyethylene pots during 5 hours to eliminate the agglomerates. The powders were then fitted in a cylindrical carbon die with an inner diameter of $20 \mathrm{~mm}$ for Spark Plasma Sintering (Dr Sinter 2080, SPS Syntex Inc.). The sintering temperature varied between $1450^{\circ} \mathrm{C}$ and $1750^{\circ} \mathrm{C}$, the heating-rate was set to $200^{\circ} \mathrm{C} / \mathrm{min}$ and the holding period varied from 1 to $20 \mathrm{~min}$ at the selected temperature. First, the powders were degassed under vacuum at $700^{\circ} \mathrm{C}$, next a mechanical pressure of $30 \mathrm{MPa}$ was applied and finally a nitrogen or argon atmosphere $\left(\mathrm{P}_{\text {gas }}=0.02 \mathrm{MPa}\right)$ was introduced in the sintering chamber. The heating process was controlled using an optical pyrometer focused on a hole in the carbon die. The axial shrinkage of the unreinforced matrix during sintering was recorded by an extensometer.

The bulk density of the samples was measured by Archimede's method. Crystalline phases were determined from X-ray diffraction patterns in Bragg-Brentano geometry (D8 advance, Bruker), using a copper anode $(\mathrm{CuK} \alpha)$.

\subsection{Elaboration of CMC}

Multidirectional fiber preforms, fabricated from ex-PAN carbon fibers were used. Their main characteristics were given in a previous paper [2].

As it is well known, the fiber/matrix bonding is a key factor controlling performances of ceramic matrix composites [15], so a pyrocarbon interphase $\left(\mathrm{PyC}_{\mathrm{i}}\right)$ was deposited on the fiber surface by CVI in order to arrest and deflect the matrix microcracks and to insure a load transfer function. 
To minimize possible chemical reactions of carbon (fibers or interphases) with the matrix constituents during the fabrication, a SiC coating $\left(\mathrm{SiC}_{\mathrm{c}}\right)$ was deposited by $\mathrm{CVI}$ on the PyC interphase. The different combinations of fibers, $\mathrm{PyC}$ interphase and $\mathrm{SiC}$ coating used in this study are: $\left\{\mathrm{C}_{\mathrm{f}} / \mathrm{PyC}_{\mathrm{i}}\right\}$ and $\left\{\mathrm{C}_{\mathrm{f}} / \mathrm{PyC}_{\mathrm{i}}\right.$ $\left.+\mathrm{SiC}_{\mathrm{c}}\right\}$

The preforms were infiltrated by a slurry impregnation under vacuum, using a suspension containing 30 vol.\% of ceramic powders $\left(\mathrm{Si}_{3} \mathrm{~N}_{4}+\mathrm{Al}_{2} \mathrm{O}_{3}+\mathrm{Y}_{2} \mathrm{O}_{3}+\mathrm{TiB}_{2}\right)$, as reported in a previous paper [2].

The impregnated preforms were then dried during $48 \mathrm{~h}$ at $25^{\circ} \mathrm{C}$. The dried carbon preforms charged with the silicon nitride + titanium diboride + sintering-aid powders were then put into a graphite die with an inner diameter of $50 \mathrm{~mm}$ for SPS. The SPS conditions are a compromise between minimizing fiber degradation and achieving full densification of the matrix. The choice of the sintering conditions resulted of the densification conditions of the monolithic matrix $\left(\mathrm{Si}_{3} \mathrm{~N}_{4}+\mathrm{TiB}_{2}+\right.$ sintering-aid powders). The sintering temperature was fixed at $1500^{\circ} \mathrm{C}$ and hold 3 min under $\mathrm{N}_{2}$ atmosphere, while the pressure was fixed at $75 \mathrm{MPa}$.

Yttria and alumina sintering-aids react in temperature with the silica layer covering the surface of silicon nitride powders to form a liquid phase that may accommodate the stress in the material due to external pressure during preparation of the CMC by SPS and, as a result, limits possible fiber damage.

To minimize fiber degradation the pressure was applied only when the sintering aids began to soften, but soon enough $\left(1300^{\circ} \mathrm{C}\right)$ to limit $\mathrm{CO}_{(\mathrm{g})}$ evolution and thus to inhibit any possible reaction of $\mathrm{Si}_{3} \mathrm{~N}_{4}$ or sintering aids with the pyrocarbon interphase or the fibers [16].

The sintered composites were subsequently cut and ground into $45 \times 12 \times 2.5 \mathrm{~mm}^{3}$ specimens. The flexural strength $(\sigma)$ is defined as the strength when the specimen fails in the 3-point bending test. It is calculated according to the equation (1):

$\sigma=3 \mathrm{FL} / 2 \mathrm{w} \mathrm{t} \mathrm{t}^{2}$ (equation 1)

Where $\mathrm{F}$ is the breaking force of the specimen, $\mathrm{L}$ the support span $(35 \mathrm{~mm})$, w the width (12 mm) and $\mathrm{t}$ the thickness $(2.5 \mathrm{~mm})$. We used a universal testing machine (Model 5569, Instrom Corp) at cross-head speed of $0.5 \mathrm{~mm} / \mathrm{min}$ at room temperature.

The polished cross sections of the composites before bending tests were characterized by scanning electron microscopy (Quanta 400 FEG, FEI) and energy-dispersive X-ray spectroscopy (EDAX). Some 
composites were oxidized under air at $850^{\circ} \mathrm{C}$ during $13 \mathrm{~h}$ and observed to study their self-healing behavior.

\section{Results and discussion}

\subsection{Elaboration of the ceramic monolithic matrix}

Figure 1 shows the shrinkage and shrinkage rate curves of the matrix $\left(66.5 \mathrm{wt} \% \mathrm{Si}_{3} \mathrm{~N}_{4}+20 \mathrm{wt} \% \mathrm{TiB}_{2}+9\right.$ wt $\% \mathrm{Y}_{2} \mathrm{O}_{3}+4.5 \mathrm{wt} \% \mathrm{Al}_{2} \mathrm{O}_{3}$ ) during sintering up to $1750^{\circ} \mathrm{C}$ at $30 \mathrm{MPa}$ under $\mathrm{N}_{2}$ atmosphere. The displacement rate curve clearly shows two maxima around $1260^{\circ} \mathrm{C}$ and $1500^{\circ} \mathrm{C}$. The first important increase in shrinkage observed around $1260^{\circ} \mathrm{C}$ can be attributed to particles rearrangement due to liquid phase formation and the second one around $1500^{\circ} \mathrm{C}$ to the dissolution-diffusion-reprecipitation densification mechanisms.

Samples sintered under $\mathrm{N}_{2}$ reach density closed to the theoretical value $\left(3.54 \mathrm{~g} / \mathrm{cm}^{3}\right)$ on the contrary of samples sintered under Ar (Figure 2).

This is due to the fact that sample sintered 6 minutes under $\mathrm{N}_{2}$ is constituted of $\beta-\mathrm{Si}_{3} \mathrm{~N}_{4}, \alpha-\mathrm{Si}_{3} \mathrm{~N}_{4}$ and $\mathrm{TiB}_{2}$ whereas sample sintered during 6 minutes under $\mathrm{Ar}$ is constituted of $\beta-\mathrm{Si}_{3} \mathrm{~N}_{4}, \mathrm{Si}$, TiN, and $\mathrm{BN}$ phases (Figure 3 and Figure 4). Thus, under Ar atmosphere, undesired chemical reactions occur in the sample. Possible explanation for the formation of $\mathrm{TiN}$ is that $\mathrm{Si}_{3} \mathrm{~N}_{4}$ decomposes forming $\mathrm{Si}$ and $\mathrm{N}_{2}$ according to reaction 1 and then $\mathrm{N}_{2}$ gas reacts with $\mathrm{TiB}_{2}$ to form $\mathrm{TiN}$ and $\mathrm{BN}$ (reaction 2).

$\mathrm{Si}_{3} \mathrm{~N}_{4}=3 \mathrm{Si}+2 \mathrm{~N}_{2}$

$2 \mathrm{TiB}_{2}+3 \mathrm{~N}_{2}=2 \mathrm{TiN}+4 \mathrm{BN}$

To explain the formation of TiN, Jones et al. suggested the above reactions (1 and 2) as well as the reaction between $\mathrm{Si}_{3} \mathrm{~N}_{4}$ and $\mathrm{TiB}_{2}$ according to reaction 3 [13].

$4 \mathrm{TiB}_{2}+3 \mathrm{Si}_{3} \mathrm{~N}_{4}=4 \mathrm{TiN}+8 \mathrm{BN}+9 \mathrm{Si}$

Furthemore, as Jones et al. did not detect Si or Si containing phases (e.g. titanium silicides) in their samples sintered by HIP at temperature bellow $1750^{\circ} \mathrm{C}$, they suggested that the above mechanisms alone (reactions 1, 2 and 3) do not adequately explain the formation of TiN [13]. As TiN was not formed adjacent to BN phase, they suggested that they were nucleated from the liquid at separate sites and that it was the activity and the kinetics of migration of species through the inter-granular liquid phase that control the rate and type of reaction that occurs. 
In samples sintered by SPS at $1500^{\circ} \mathrm{C}$ as the formation of $\mathrm{TiN}$ is only detected under Ar atmosphere and not under $\mathrm{N}_{2}$ atmosphere, it is unlikely that reaction 3 is the main reaction explaining the formation of TiN.

From our results, there is no evidence that other mechanisms, as suggested by Jones et al., cannot happen to explain the formation of $\mathrm{TiN}$.

Sun et al. fabricated $\mathrm{Si}_{3} \mathrm{~N}_{4}+\mathrm{TiB}_{2}$ samples by $\mathrm{HP}$ at $1800^{\circ} \mathrm{C}$ for $1 \mathrm{~h}$ in $\mathrm{N}_{2}$ atmosphere [14]. They detected the presence of TiSi that they explained by the reaction of $\mathrm{Si}_{3} \mathrm{~N}_{4}, \mathrm{TiB}_{2}$ and $\mathrm{N}_{2}$ according to reaction 4 .

$\mathrm{Si}_{3} \mathrm{~N}_{4}+3 \mathrm{TiB}_{2}+\mathrm{N}_{2}=3 \mathrm{TiSi}+6 \mathrm{BN}$

As TiSi was not detected in our samples sintered by SPS, reaction 4 is unlikely to happen in our materials.

As we want to maintain $\mathrm{TiB}_{2}$ (one of the healing compound generator), the sintering conditions chosen to densify by SPS the $\mathrm{Si}_{3} \mathrm{~N}_{4}+\mathrm{TiB}_{2}$ matrix are a thermal treatment at $1500^{\circ} \mathrm{C}$ applied during 3 minutes at 30 $\mathrm{MPa}$, under $\mathrm{N}_{2}$ atmosphere.

\subsection{Elaboration of CMC by SPS}

After the under-vacuum slurry infusion step, the inter-tows porosity of the preform is filled homogenously by the mineral charges as can be seen on Figure 5.

The microstructures of the composites were studied in term of fiber degradation, densification of the inter and intra-tows matrix, microcracks inside the matrix, decohesions between the fibers and the matrix and will be successively discussed.

The inter-tows matrix of composites is fully dense (Figure 6) except in some located areas (Figure 6d) between crossing tows for $\mathrm{C}$-fibers composites with a $\mathrm{SiC}$ coating around the fibers. This lies in the fact that the $\mathrm{SiC}$ coating withstands the transmission of the pressure to the matrix located at the crossing of the tows [2].

Inside the tows the fibers are bonded by the pyrocarbon and eventually by the $\mathrm{SiC}$ coating. Carbon fiber composites without $\mathrm{SiC}$ coating have some intra-tow areas densified by the $\mathrm{Si}_{3} \mathrm{~N}_{4}$-based matrix. For carbon fiber composites with the $\mathrm{SiC}$ coating, the accessibility to the intra-tow porosity is blocked by the SiC layer prior to powder impregnation.

The composites made of $\mathrm{C}_{\mathrm{f}} / \mathrm{PyC}_{\mathrm{i}} /\left(\mathrm{Si}_{3} \mathrm{~N}_{4}+\mathrm{TiB}_{2}\right)$ matrix exhibit microcracks after fabrication (Figure 6). These microcracks are the result of the CTE mismatch between the carbon-fibers and the $\mathrm{Si}_{3} \mathrm{~N}_{4}+\mathrm{TiB}_{2}$ 
matrix. Sabouret et al. have computed around $450 \mathrm{MPa}$ the internal stress inside the matrix in unidirectional carbon fiber-reinforced $\mathrm{Si}_{3} \mathrm{~N}_{4}$ matrix composite (with $\mathrm{E}_{\mathrm{C} \text {-fiber }}=250 \mathrm{GPa}$ ) [17]. In our multidirectional C-fiber arrangement composites studied, the repartition of the thermal stresses inside the matrix is more complicated than in unidirectional composites but theses stresses are higher than the intrinsic stress at failure of the matrix, which leads to the formation of cracks inside the matrix.

No important decohesion between the fibers and the interphase/coating is observed. The thickness of PyC interphase can accommodate some strain differences between the constituents of the composite and, furthermore carbon fibers show no radial strain. Some decohesions or cracks between the PyC interphase or the SiC coating and the matrix are observed. These decohesions may be the result of thermal stresses produced by the CTE mismatch between the C-fiber and the matrix or to some preferential shrinkage of the matrix not followed by the displacement of the fiber-tows.

The stress-displacement curves obtain during bending mechanical tests at ambient temperature are presented in Figure 7. C-fibers composites exhibit a damageable behavior with the maximum stress at failure around $300 \mathrm{MPa}$ which is closed to the one of $\mathrm{C}_{\mathrm{f}} / \mathrm{SiC}_{\mathrm{m}}$ composite processed by CVI process [18]. The presence of the $\mathrm{SiC}$ coating around the fibers enhances the mechanical properties. The hypotheses formulated to explain this point are that $(i)$ the strength of the interface bond between the SiC coating and the matrix phases (more precisely the intergranular $\mathrm{SiO}_{2}-\mathrm{Y}_{2} \mathrm{O}_{3}-\mathrm{Al}_{2} \mathrm{O}_{3}$ glassy phase) is stronger than the bond between the PyC interphase and the amorphous matrix phase, (ii) as the strain at failure of the composites with and without $\mathrm{SiC}$ coating are more or less the same, the increase in ultimate stress for the composite with $\mathrm{SiC}$ coating is due to the increase of the elastic modulus of the composite by the $\mathrm{SiC}$ coating and (iii) the $\mathrm{SiC}$ coating prevented the fibers from chemical degradation during the fabrication. However, as fiber degradations were not observed in the material without the SiC coating, the last hypothesis is improbable.

\subsection{Oxidation behavior of the CMC}

At $850^{\circ} \mathrm{C}$ under air, the $\left(\mathrm{TiB}_{2}\right.$ and $\left.\mathrm{Si}_{3} \mathrm{~N}_{4}\right)$ matrix oxidation is described by the following reactions:

$2 \mathrm{TiB}_{2}+5 \mathrm{O}_{2}=2 \mathrm{TiO}_{2}+2 \mathrm{~B}_{2} \mathrm{O}_{3}$

$\mathrm{Si}_{3} \mathrm{~N}_{4}+3 \mathrm{O}_{2}=3 \mathrm{SiO}_{2}+2 \mathrm{~N}_{2}$

At this temperature, another reaction between $\mathrm{B}_{2} \mathrm{O}_{3}$ and $\mathrm{SiO}_{2}$ occurs and leads to an amorphous phase with a relatively low melting point: the healing fluid. On the Figure 8 it appears that the cracks seem to be 
healed inside the matrix since they cannot be observed after $13 \mathrm{~h}$ under air at $850^{\circ} \mathrm{C}$. Moreover, the oxidation of $\mathrm{TiB} 2$ leads to the formation of $\mathrm{TiO}_{2}$ grains (reaction 5) which are covering the matrix surface (due to an increase of 1.64 in the molar volume [19]) and can act as an environmental barrier.

Further characterizations on the self-healing behavior of this material are under progress.

\section{CONCLUSION}

Ceramic matrix composites with a complex matrix were successfully processed by a short time hybrid process based on chemical vapor infiltration fiber coating, on the introduction of $\mathrm{Si}_{3} \mathrm{~N}_{4}+\mathrm{TiB}_{2}+$ sinteringaids powders inside the fiber preform by slurry impregnation and on the consolidation of the composite by spark plasma sintering. This process is achieved at $1500^{\circ} \mathrm{C}$ for 3 minutes under $75 \mathrm{MPa}$ mechanical pressure and $\mathrm{N}_{2}$ atmosphere rising to a dense matrix without fiber degradation. The ceramic matrix composite shows a high bending stress at failure $(\approx 300 \mathrm{MPa})$ and a self-healing behavior in oxidizing conditions.

\section{ACKNOWLEDGEMENTS}

This work was supported by DGA (Direction Générale pour l'Armement from France) and Herakles (Safran Group) through a grant. The authors acknowledge E. Philippe and S. Bertrand (Herakles) for material supply; G. Chevallier, C. Estournes and G. Raimbeaux ( $\mathrm{PNF}^{2}$, University of Toulouse, France) for Spark Plasma Sintering experiments.

\section{REFERENCES}

${ }^{1}$ G. Grenet, L. Plunkett, J.B. Veyret, E. Bullock: Proceeding HTCMC II, Manufacturing and materials Development, 1995, 125.

2 J. Magnant, R. Pailler, Y. Le Petitcorps, L. Maillé, A. Guette, J. Marthe, and E. Philippe, Fiberreinforced ceramic matrix composites processed by a hybrid technique based on chemical vapor infiltration, slurry impregnation and spark plasma sintering, J. Europ. Ceram. Soc. 2012, 33, 181.

${ }^{3}$ F. Lamouroux, G. Camus, J. Thébault, J. Am. Ceram. Soc., 1994, 77: 2049.

${ }^{4}$ L. Filipuzzi, G. Camus, R. Naslain, J. Thebault, J. Amer. Ceram. Soc., 1994, 77, 459. 
${ }^{5}$ R. Naslain, R. Pailler, X. Bourrat, S. Bertrand, F. Heurtevent, P. Dupel, and F. Lamouroux: Solid State Ionics, 2001, 141, 541 .

${ }^{6}$ S. Goujard, L. Vandenbulcke: Ceram.Trans., 1994, 46, 925.

${ }^{7}$ KN. Lee, D. S. Fox, R. C. Robinson, N. P. Bansal: High Temperature Ceramic Matrix Composites, $2001,224$.

${ }^{8}$ F. Lamouroux, F., S. Bertrand, R. Pailler, R. Naslain: Key Engin. Mater., 1999, 164, 365.

${ }^{9}$ FL. Riley: J. Am. Ceram. Soc., 2000, 83, 245.

${ }^{10}$ B. Basu, G.B. Raju, A.K. Suri: International Materials Reviews, 2006, 51, 352.

${ }^{11}$ Y.H. Koh, S.Y. Lee, H.E. Kim: J. Am. Ceram. Soc., 2001, 84, 239.

${ }^{12}$ A. Kulpa, T. Troczynski: J. Am. Ceram. Soc., 1996, 79, 518.

${ }^{13}$ A.H. Jones, R.S. Dobedoe, M.H. Lewis: J. Europ. Ceram. Soc., 2001, 21, 969.

${ }^{14}$ Y. Sun, Q. Meng, D.C. Jia, L.J. Huang: Materials Letters, 2004, 58, 2057.

${ }^{15}$ J.F. Després, M. Monthioux, Mechanical properties of $\mathrm{C} / \mathrm{SiC}$ composites as explained from their interfacial features, J. Europ. Ceram. Soc., 15, 209-224 (1995).

${ }^{16}$ K. L. Luthra, H. D. Park: J. Am. Ceram. Soc., 1992, 75, 1889.

${ }^{17}$ E. Sabouret, Composites à matrice Nitrure de Silicium et fibres de carbone : Elaboration, comportement mécanique, PhD Thesis, University of Limoges-France (1996).

${ }^{18}$ N. Eberling-Fux, Matériaux composites à matrice nanostructurée, PhD Thesis, University of BordeauxFrance (2003).

${ }^{19}$ E. Garrite, Etude de l'oxydation/corrosion des composites céramiques, $\mathrm{PhD}$ Thesis, University of Bordeaux-France (2007). 


\section{List of figure and table captions}

Figure 1. Temperature and shrinkage rate of the sample during the SPS cycle.

Figure 2. Variation of the matrix density with the SPS processing parameters at $1500^{\circ} \mathrm{C}, 30 \mathrm{MPa}$ for different dwelling periods and atmosphere.

Figure 3. Variation of the XRD patterns of the matrix after SPS at $1500^{\circ} \mathrm{C}, 30 \mathrm{MPa}$ according to different dwelling periods under Ar or $\mathrm{N}_{2}$ atmosphere.

Figure 4. Back-scattered $\mathrm{SEM}$ micrographs of $66.5 \mathrm{wt} \% \mathrm{Si}_{3} \mathrm{~N}_{4}+20 \mathrm{wt} \% \mathrm{TiB}_{2}+4.5 \mathrm{wt} \% \mathrm{Al}_{2} \mathrm{O}_{3}+9 \mathrm{wt} \%$ $\mathrm{Y}_{2} \mathrm{O}_{3}$ samples sintered at $1500^{\circ} \mathrm{C}$ during 6 min (a) under $\mathrm{Ar}$, and (b) under $\mathrm{N}_{2}$ atmosphere. In (a) silicon and titanium nitride correspond to the white phase contrast, silicon nitride to the grey contrast and boron nitride is in black. In (b) titanium diboride are the light grey inclusions and the silicon nitride corresponds to the dark grey contrast.

Figure 5. Micrographs of fiber preforms (a) before impregnation by the mineral powder and (b) after impregnation. The powders correspond to the grey contrast between the tows.

Figure 6. SEM micrographs of Spark Plasma Sintered composites (a) and (b) $\mathrm{C}_{\mathrm{f}} / \mathrm{PyC}_{\mathrm{i}} / \mathrm{Si}_{3} \mathrm{~N}_{4 \mathrm{~m}}+\mathrm{TiB}_{2 \mathrm{~m}}$, (c) and (d) $\mathrm{C}_{\mathrm{f}} / \mathrm{PyC}_{\mathrm{i}}+\mathrm{SiC}_{\mathrm{c}} / \mathrm{Si}_{3} \mathrm{~N}_{4 \mathrm{~m}}+\mathrm{TiB}_{2 \mathrm{~m}}$

Figure 7. Stress/displacement curves from bending test for composites sintered by SPS with a $75 \mathrm{MPa}$ mechanical pressure applied at $1300^{\circ} \mathrm{C}$

Figure 8. SEM back-scattered micrographs of $\mathrm{C}_{\mathrm{f}} / \mathrm{Si}_{3} \mathrm{~N}_{4}+\mathrm{TiB}_{2}$ after oxidation under air at $850^{\circ} \mathrm{C}-13 \mathrm{~h}$ showing the cracks healing.

Table I. Some characteristics of the powders used. 


\section{Figure 1}

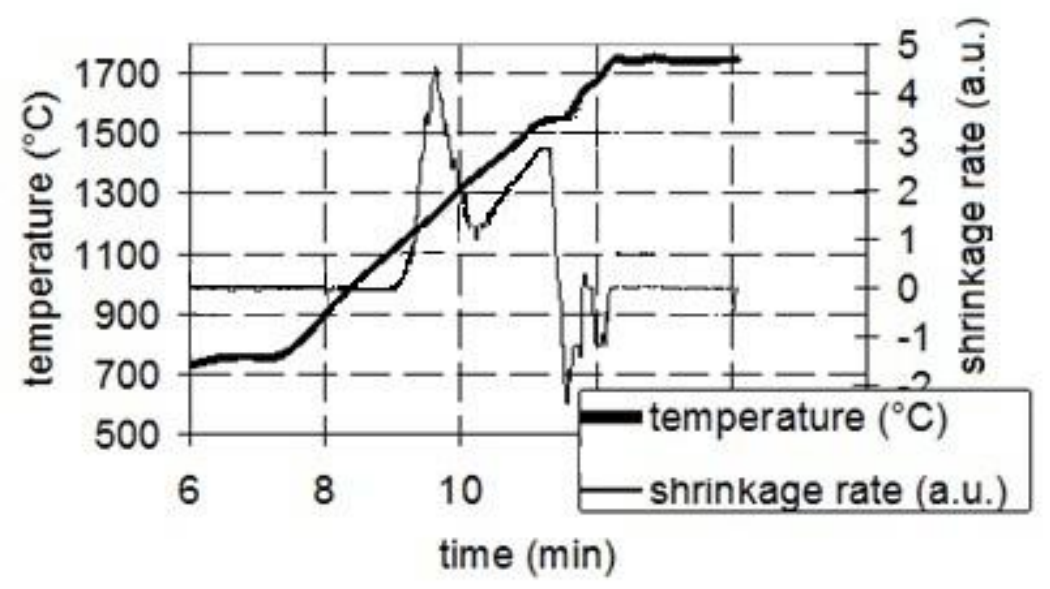

Figure 2

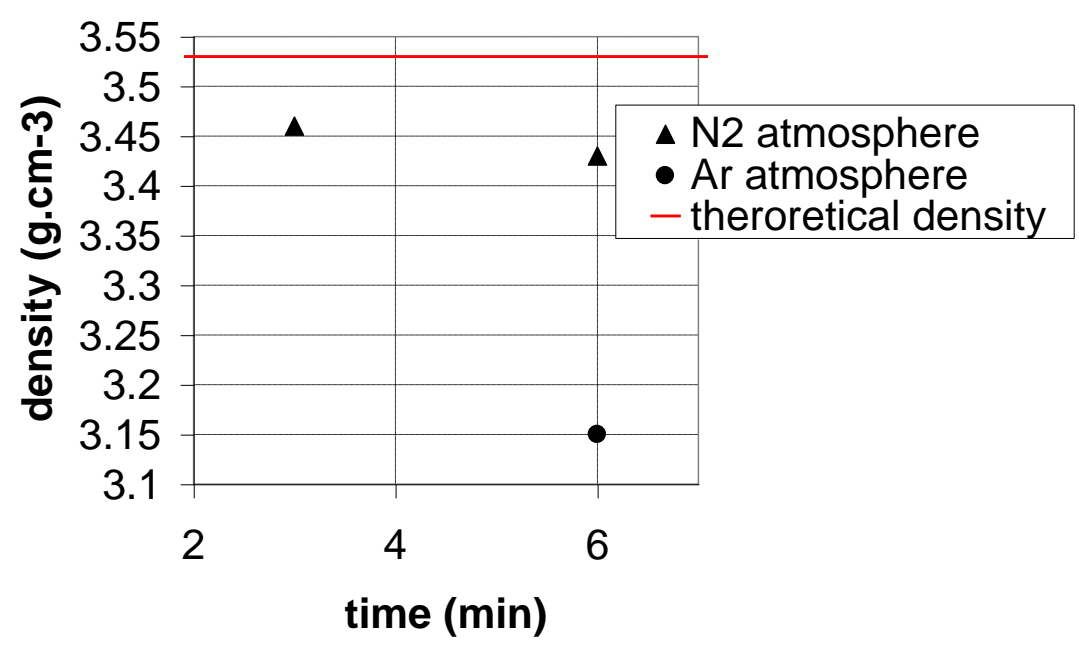

Figure 3

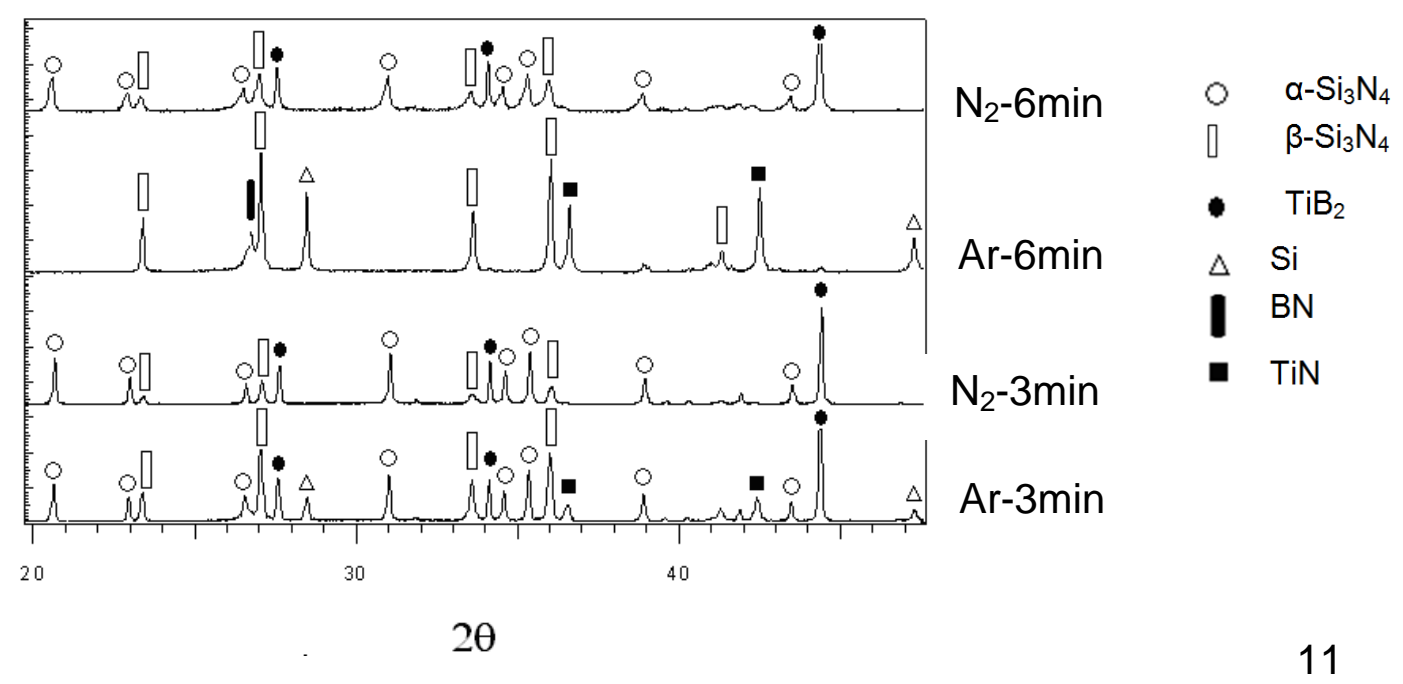




\section{Figure 4}

(a) $\mathrm{Ar}$

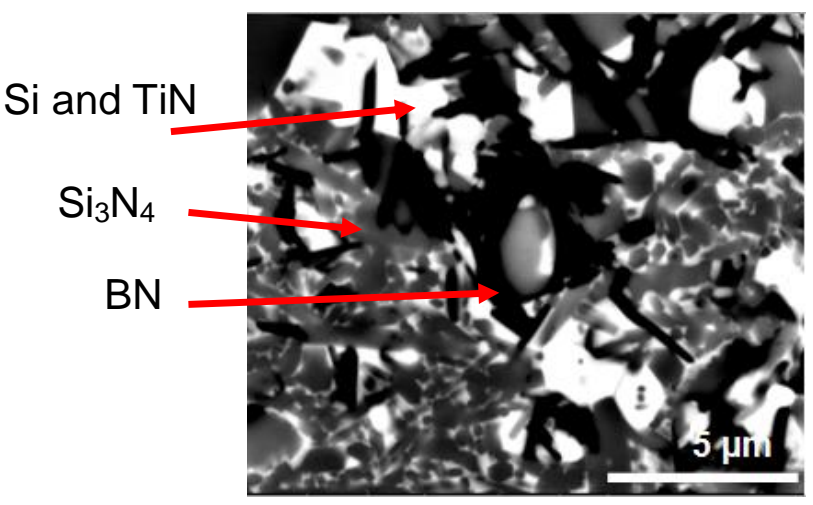

(b) $\mathrm{N}_{2}$

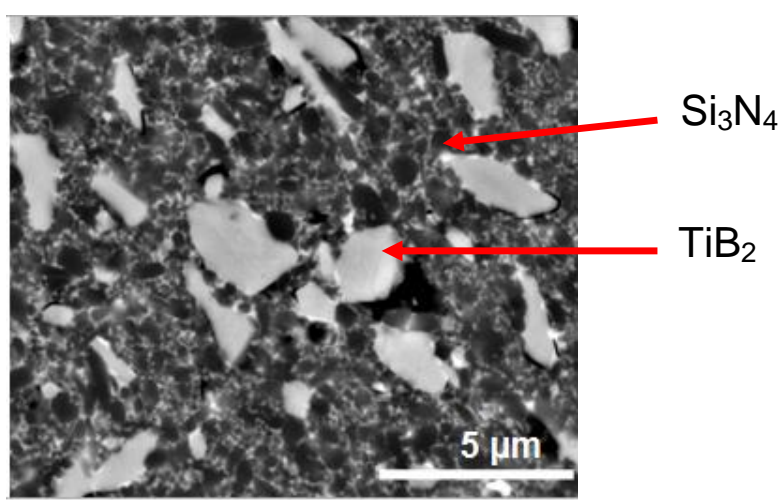

\section{Figure 5}
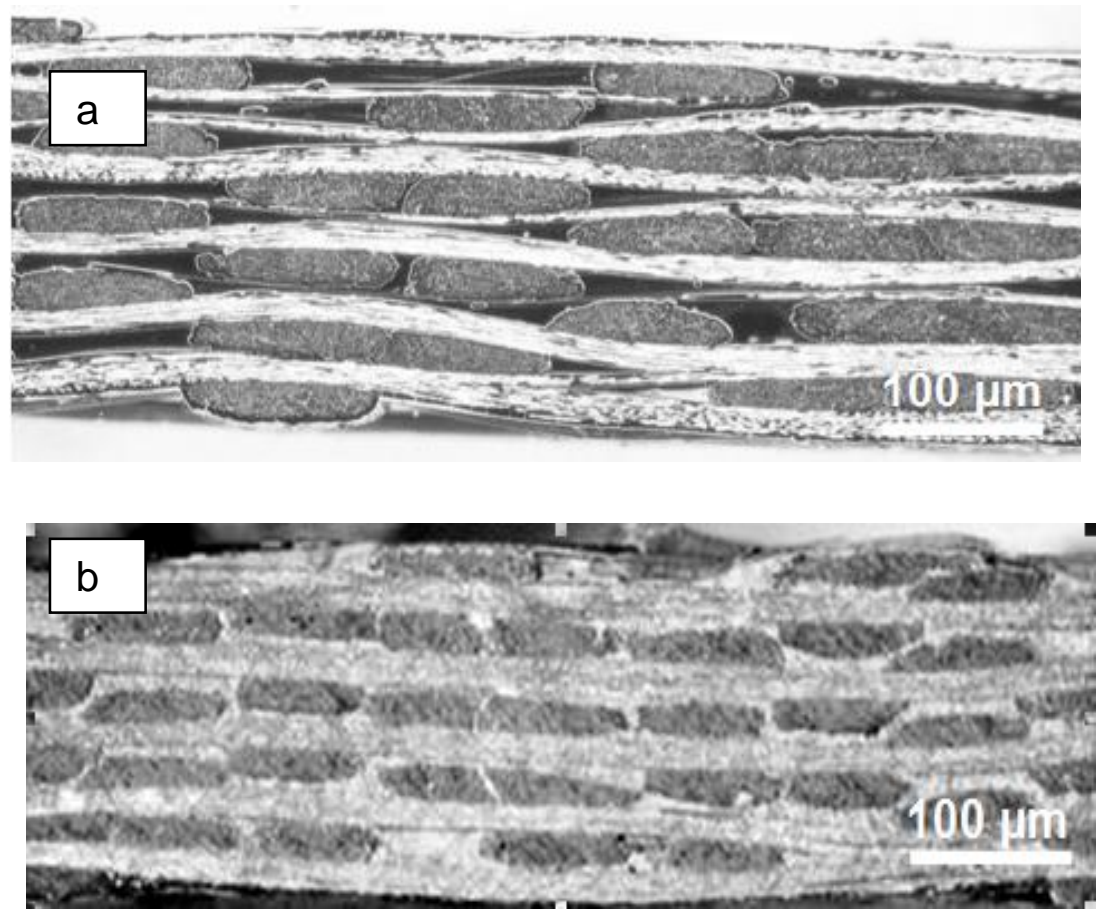


\section{Figure 6}
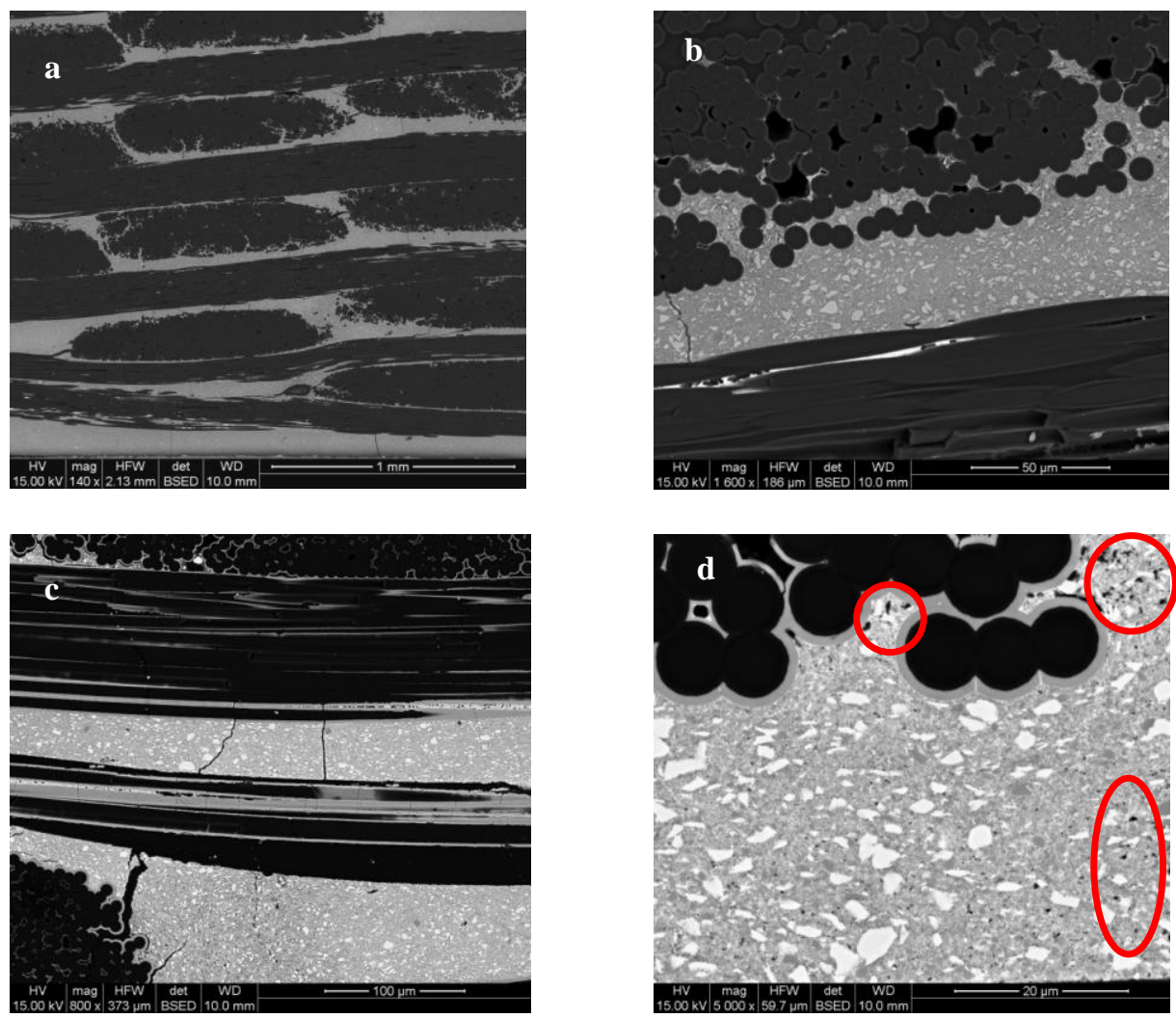

Figure 7

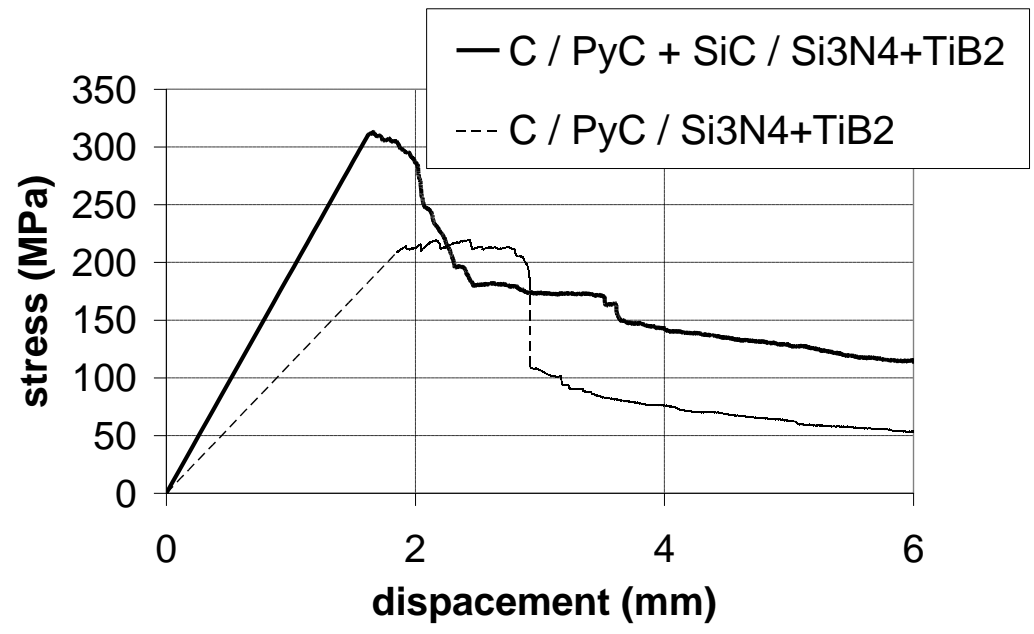




\section{Figure 8}
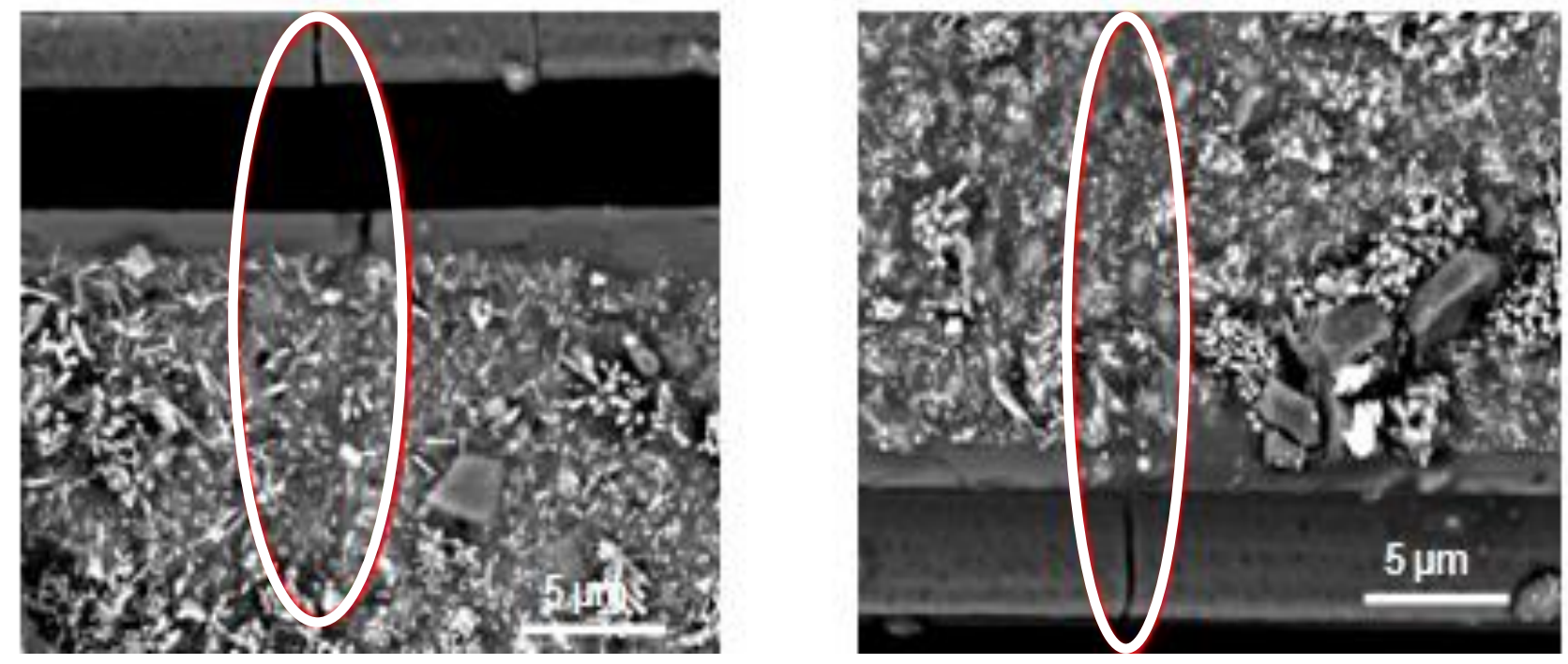

\section{Table I}

\begin{tabular}{|l|c|c|c|c|}
\hline & $\mathrm{Si}_{3} \mathrm{~N}_{4}$ & $\mathrm{TiB}_{2}$ & $\mathrm{Y}_{2} \mathrm{O}_{3}$ & $\mathrm{Al}_{2} \mathrm{O}_{3}$ \\
\hline Provider & $\mathrm{HC}$ & $\mathrm{HC}$ & $\mathrm{HC}$ & Alfa Aesar \\
& Starck & Starck & Starck & \\
\hline grade & $\mathrm{M} 11$ & $\mathrm{~F}$ & $\mathrm{C}$ & - \\
\hline SSA & $12-15$ & 2.7 & $10-16$ & 10 \\
$\left(\mathrm{~m}^{2} \cdot \mathrm{g}^{-1}\right)$ & & & & \\
\hline
\end{tabular}

